\title{
Diplomasi RI di Mesir dan Negara-Negara Arab pada Tahun 1947
}

\author{
Suranta Abd. Rahman
}

\begin{abstract}
In 1947, the Republic of Indonesia (RI) sent a diplomatic mission to seek the international community's acknowledgement for the nation's independence. The mission in the Arab nations, particularly in Egypt, was severely challenged by the Netherlands. However, with a spirit of solidarity, the people and government of Egypt supported the struggle and acknowledged RI's independence, de facto and de jure. Diplomacy was implemented in maintaining RI's sovereignty which was threatened to be retaken by the Netherlands. Meanwhile, the struggles in military area were maintained to dissipate the Netherlands from Indonesia.
\end{abstract}

KeYwords Diplomacy, Independence Acknowledgement of RI, Indonesia, Arab Countries, Egypt.

Diplomasi bangsa Indonesia di luar negeri untuk mendapatkan pengakuan kemerdekaan secara de facto dan de jure menghadapi tantangan dan hambatan yang panjang dan berat. Pemerintah Hindia Belanda dan sekutunya berusaha menutup jalan diplomasi bangsa Indonesia. Perjalanan panjang Misi Diplomatik RI di negara-negara Arab, khususnya di Mesir, mendapat tantangan dari pihak Kedutaan Besar Belanda di negara Arab. Pemerintah Belanda berusaha merintangi jalan dan menghasut bahwa para diplomat RI adalah kolaborator Jepang. Akan tetapi, usaha Belanda dapat dipatahkan oleh Misi Diplomatik RI yang didukung oleh para mahasiswa yang belajar di Universitas Al-Azhar sehingga dapat meyakinkan Pemerintah Mesir untuk mendukung kemerdekaan dan pengakuan kedaulatan RI.

Pemerintah Mesir memberikan dukungan moril dan materiil kepada Indonesia. Dukungan tersebut berupa pernyataan Pemerintah Mesir pada tanggal 23 Maret 1946 sebagai negara Arab pertama yang mengakui kemerdekaan RI secara de facto di samping Inggris, Amerika Serikat, Australia, dan Belanda sendiri. Pengakuan Pemerintah Mesir ini sebagai landasan utama Diplomasi RI di luar negeri yang mendapatkan legitimasi kuat dalam forum internasional dan mendorong negara-negara Arab lainnya 
untuk mengakui kemerdekaan RI (Hassan1980:124). Di samping itu, untuk memperkuat dukungan internasional, Pemerintah Mesir merealisasikan sebuah perjanjian persahabatan dengan Indonesia pada tahun 1947. Dalam kaitan ini, Abdurrahman Azzam Pasya, Sekretaris Jenderal Liga Arab sangat berperan dalam proses pengakuan negara-negara Arab terhadap kemerdekaan RI (Waal 1948: 263).

Diplomasi RI di Mesir memiliki arti penting dalam sejarah hubungan Indonesia-Mesir. Pertama, kedudukan Mesir begitu dominan dalam kebijakan politik negara-negara Arab karena menjadi basis dan pemegang kendali Liga Arab. Kedua, dengan menganalisis dukungan Mesir terhadap kemerdekaan RI menjadi sarana yang tepat untuk memahami sejarah hubungan IndonesiaMesir yang telah terbentuk sejak sebelum proklamasi kemerdekaan. Ketiga, untuk menjawab pertanyaan mengapa Mesir begitu kuat mendukung RI. Tulisan ini berusaha mengungkapkan semangat perjuangan diplomasi Indonesia pascaproklamasi kemerdekaan yang tercermin dalam pergerakan pelajar dan mahasiswa Indonesia yang belajar di Univeritas Al-Azhar, Mesir; baik dalam bentuk protes dan tentangan terhadap kebijakan Pemerintah Belanda mengenai Indonesia melalui kedutaannya di Mesir maupun tulisan kritis mereka tentang Indonesia yang disebarkan dalam surat kabar Mesir. Selain itu, tulisan ini menjelaskan bagaimana diplomasi yang dijalankan oleh misi diplomatik RI dapat menarik simpati negara-negara Arab untuk mengakui kemerdekaan Indonesia. Sementara itu, dukungan Mesir dan Liga Arab dengan semangat nasionalisme Arab memiliki peran yang signifikan dalam proses mendapatkan pengakuan internasional bagi kemerdekaan RI.

Permasalahan yang perlu diketahui dalam penulisan ini adalah apa yang dilakukan oleh Misi Diplomatik RI untuk mendapatkan pengakuan kemerdekaan dari Pemerintah Mesir?

Tulisan ini menjelaskan proses diplomasi RI di Mesir yang dimulai dengan menganalisis aktivitas Misi Diplomatik RI di Mesir pada tahun 1947. Dengan demikian, menjadi tujuan penulis ini untuk menjawab secara lebih jelas pertanyaan berikut.

1. Mengapa RI mencari dukungan dari Mesir dan negara Arab?

2. Mengapa Mesir memberikan dukungan terhadap kemerdekaan RI?

3. Apa yang menjadi faktor pendukung dan penghambat diplomasi?

Tulisan ini juga bertujuan untuk memberikan sumbangan yang bermanfaat bagi penulisan sejarah Diplomasi RI. Selain itu, hubungan Indonesia Mesir perlu terus diaktualisasikan dan dilestarikan agar semakin kokoh.

Metode penelitian yang digunakan bersifat deskriptif-analitis yaitu menggambarkan dan manganalisis peristiwa yang terjadi secara kronologis. Analisis dilakukan dengan mengikuti kaidah dan prosedur yang berlaku dalam penelitian sejarah yang terdiri dari empat tahap dan diterapkan secara berkesinambungan, yaitu heuristik, kritik, interpretasi, dan historiografi. 


\section{HUBUNGAN INDONESIA MESIR}

Kedatangan pelajar dan mahasiswa Indonesia ke Mesir pada abad ke-19 dipengaruhi oleh semangat menuntut ilmu, khususnya ilmu agama Islam di Universitas Al-Azhar yang menjadi pusat ilmu pengetahuan Islam setelah Mekkah dan Madinah. Hubungan Indonesia-Mesir secara signifikan terjadi setelah Perang Dunia I ketika seorang mahasiswa Indonesia Syekh Ismail Muhammad Al-Jawi mendirikan Riwaq Jawi atau Ruak Jawa (asrama Jawa) di Universitas Al-Azhar. Kata "Jawa" digunakan sebagai pengganti kata "Indonesia" di negara-negara Arab karena, di masa penjajahan, Jawa menjadi pusat pemerintahan, kebudayaan, pendidikan, dan ekspor-impor. Maka, segala sesuatu yang datang dari Indonesia dinamakan Jawi, berarti dari Jawa, seperti teh Jawi, gula Jawi, dan kemenyan Jawi (Fachruddin 1995: 82).

Kata "Jawa" pada waktu itu tidak hanya ditujukan untuk Indonesia saja, tetapi meliputi Malaysia, Filipina, Thailand, atau negara-negara di Asia Tenggara sekarang ini. Ruak Jawa merupakan ruak kecil terletak di antara Riwaq Salmaniyyah yang meliputi mahasiswa dari Afghanistan dan Khurasan, dan Riwaq Al-Shawam untuk orang Syria. Akan tetapi, jumlah orang yang menempati Ruak Jawa sangat sedikit, hanya 11 orang, sesuai dengan jumlah potongan roti yang dibagikan untuk ruak tersebut. Pada waktu itu, Ruak Jawa yang dipimpin oleh Syekh Ismail Muhammad Al-Jawi juga memiliki sebuah perpustakaan (Abaza 1999: 31). Dalam perjalanan sejarah hubungan Indonesia-Mesir, keberadaan mahasiswa Indonesia memainkan peranan penting dalam mempercepat proses pengakuan negara-negara Arab terhadap Kemerdekaan RI. Para mahasiswa itulah yang melakukan pendekatan terusmenerus terhadap pejabat Mesir dan wakil negara-negara Arab lainnya, terutama di Iskandariah ketika berkumpul dalam rangka membentuk Liga Arab (Alatas 1995: 14).

Hubungan resmi Indonesia-Mesir terjadi pada tanggal 14 September 1923 ketika Pemerintah Mesir memberikan surat izin resmi No. 323 kepada mahasiswa Indonesia untuk mendirikan sebuah perhimpunan yang bergerak di bidang sosial dan politis. Selanjutnya, dalam pergerakan kemerdekaan, para mahasiswa diperbolehkan menerbitkan majalah politis, seperti Seruan Al-Azhar, Pilihan Timur, Merdeka, dan Usaha Pemuda. Kemudian, didirikan Persatuan Pemuda Indonesia-Malaya (Perpindom) di bawah pimpinan Ismail Banda yang bergerak khusus di bidang politis. Aksi yang dilakukan adalah menolak kerja sama dengan penjajah dan mempunyai kesadaran rumpun bangsa Indonesia-Malaya. Di Saudi Arabia didirikan Pertindom (Persatuan Talabah Indonesia-Malaya), dan di Irak didirikan Makindom atau Majlis Kebangsaan Indonesia-Malaya (Hassan 1980: 77).

Kebangkitan nasionalisme Indonesia di kalangan pelajar dan mahasiwa Indonesia di Mesir disebabkan oleh kuatnya pengaruh nasionalisme Arab dan pengaruh gerakan reformasi Islam yang telah diperkenalkan, antara lain, oleh Ibnu Taimiyah, Jamaluddin Al-Afghani, dan Mohammad Abduh. Nasionalisme Indonesia dan nasionalisme Arab dalam permulaan abad ke-20 itu merupakan dua mata cincin dari rantai panjangnya kebangkitan 
nasionalisme di seluruh benua Asia dan Afrika (Abdul Ghani1978: 41).

Sebelum kemerdekaan, berita tentang Indonesia diterima di negaranegara Arab dan telah disebarluaskan melalui berbagai media, baik lisan maupun tulis. Hal itu mendapat perhatian khalayak umum di Mesir, baik kalangan partai, perkumpulan agama, maupun rakyat biasa. Dalam tahap perlawanan tersebut, para mahasiswa menghadapi masa-masa sulit karena perang dan putusnya hubungan antara mahasiswa dan keluarga di Indonesia. Sementara itu, Kedutaan Belanda tidak mau memberi bantuan keuangan kepada para mahasiswa. Setelah protes mahasiswa yang mendapat dukungan polisi Mesir, akhirnya Kedutaan Besar Belanda mengabulkan permintaan mahasiswa dengan memberikan bantuan keuangan yang sangat kecil. Akan tetapi, mahasiswa tidak mau menerima bantuan itu sebagai "pemberian", tetapi hanya sebagai "utang". Sikap ini menjadi cemoohan Duta Besar Belanda di Mesir yang menyatakan, dalam laporannya kepada Menteri Luar Negeri Belanda, bahwa kebanggaan nasional mahasiswa Indonesia yang disebarluaskan dalam laporan pers itu tidak mampu bertahan terhadap kebutuhan dunia (Waal 1948: 88 -89).

Propaganda kemerdekaan yang dilakukan oleh mahasiswa Indonesia itu tidak saja dilakukan di Mesir, tetapi di semua negara Arab dan Eropa, seperti Belanda. Pada tahun 1926, Janan Thaib, ketua Jami'ah Al-Khairiah Al-Talabijja Al-Azhariah Al-Jawah (Perhimpunan Kebaktian Mahasiswa Jawa Universitas Al-Azhar) diutus ke negeri Belanda untuk menemui Muhammad Hatta, Ketua Perhimpunan Indonesia di Belanda, dalam rangka koordinasi perjuangan Indonesia di luar negeri. Pada masa itu, propaganda kemerdekaan dijalankan secara pasif dan di bawah tanah karena mata-mata Belanda tersebar di negara Arab. Mereka belum berani menggunakan nama "Indonesia" dalam gerakan dan persatuan mahasiswa secara terbuka, apalagi gerakan yang condong ke arah kegiatan politis. Nama "Jawa" lebih aman digunakan dalam kegiatan organisasi yang mereka jalankan, seperti Jami'ah Al-Khairiah Al-Talabijja AlAzhariah Al-Jawah. Hal itu dilakukan agar perjuangan mereka dapat terus dilakukan meskipun Belanda berusaha untuk memadamkannya. Organisasi sosial yang mereka dirikan tersebut menghimpun semua mahasiswa Indonesia yang belajar di Universitas Al-Azhar, Kairo (Abaza 1999: 77).

Setelah proklamasi kemerdekaan, nama "Indonesia" dijadikan nama setiap organisasi dan perhimpunan Indonesia secara terbuka di Mesir, seperti Perhimpunan Kemerdekaan Indonesia (PKI). Pada waktu itu, Perhimpunan Kemerdekaan Indonesia (Panitia) ${ }^{1}$ yang berkedudukan di Kairo de facto sebagai "perwakilan" sementara Pemerintah RI. Perjuangan Panitia mendapatkan tanggapan dan bantuan yang sangat berharga dari bangsa Mesir (Hassan 1980: 61 -71). Rencana kerja Panitia di antaranya berusaha menciptakan de facto kebebasan warga Indonesia di luar negeri dari "perwalian" Belanda, mendapatkan pengakuan de facto dan de jure bagi RI yang merdeka dan

Dalam kegiatan propaganda kemerdekaan Indonesia, mahasiswa menggunakan kata "Panitia" saja untuk menghindarkan kekeliruan dengan nama sebuah gerakan partai yang berhaluan komunis di Indonesia, PKI (Partai Komunis Indonesia). 
berdaulat, mendesak penarikan tentara Inggris, menuntut pembubaran NICA (Netherlands Indies Civil Administration), dan mengusahakan partisipasi wakil RI dalam setiap pertemuan internasional tentang masalah Indonesia (Suwarno 1999: 261).

Sementara itu, perjuangan kemerdekaan yang dilakukan oleh mahasiswa menghadapi tantangan berat dari pihak Belanda yang berusaha menutup setiap jalan dan jaringan mereka dalam mempertahankan kemerdekaan di luar negeri. Pada bulan pertama setelah diproklamasikan, muncul tuduhan bahwa RI adalah "buatan Jepang" sedangkan Soekarno-Hatta dianggap sebagai "kolaborator". Di samping itu, Kedutaan Belanda di Mesir berusaha memengaruhi mahasiswa Indonesia yang belajar di Universitas Al-Azhar untuk menerima bantuan keuangan dari Pemerintah Belanda dan sekaligus mengakui kembali kedaulatannya di Indonesia. Hal itu mengakibatkan mahasiswa memprotes dan menentangnya dengan melakukan demontrasi di depan Kedutaan Belanda di Mesir. Para mahasiswa tidak mau menandatangani kuitansi bantuan keuangan Belanda, bahkan mereka membakar paspor yang dikeluarkan oleh Pemerintah Belanda. Usaha Belanda untuk memadamkan perjuangan mahasiswa tidak sampai di situ saja. Ketika perjanjian persahabatan akan ditandatangani oleh wakil Pemerintah Indonesia dan Mesir, Duta Besar Belanda di Mesir berusaha menggagalkan-nya, bahkan mengancam pemutusan hubungan diplomatisnya dengan Mesir.

Upaya Belanda tersebut dapat dihambat oleh mahasiswa Indonesia dengan adanya informasi tentang Indonesia dan tentang Soekarno-Hatta yang dimuat dalam surat kabar Mesir yang telah diperkenalkan sebelum proklamasi. Misi diplomatis RI yang dikirim ke Mesir telah diratakan jalannya oleh mahasiswa Indonesia. Kedatangan misi diplomatis RI sangat ditunggutunggu oleh mahasiswa untuk merealisasikan dukungan bangsa Arab terhadap perjuangan kemerdekaan mereka. Begitu juga Pemerintah Mesir dapat melaksanakan amanat Liga Arab yang mendesak negara anggotanya untuk segera mengakui kemerdekaan RI.

\section{Masalah Indonesia Dalam SidAng PbB}

Sidang Dewan Keamanan PBB di New York pada 31 Juli 1947 yang membicarakan status RI dimulai. Pada waktu itu, wakil Australia Kolonel Hudgson memajukan masalah RI agar masuk dalam acara sidang. Kolonel Hudgson mengharapkan agar Dewan Keamanan menghentikan permusuhan yang berkobar di wilayah RI sejak pasukan Belanda menyerang pada tanggal 21 Juli 1947. Usul Australia untuk mengundang wakil RI yang didukung oleh India, Belgia, dan Uni Soviet dibantah oleh wakil Belanda, Van Kleffens yang menyatakan bahwa RI tidak pernah menjadi negara yang berdaulat. Tidak ada alasan untuk meminta kesatuan politis semacam itu untuk duduk di kursi Dewan Keamanan karena RI belum pernah diakui sebagai negara yang berdaulat oleh siapa pun. Akan tetapi, Kolonel Hudgson mengungkapkan fakta bahwa RI adalah satu negara. Pertama, rencana Persetujuan BelandaIndonesia tanggal 15 November 1946 ditandatangani oleh kedua negara, 
Belanda dan RI. Kedua, Pemerintah RI telah diakui oleh Pemerintah Belanda, sebagai Pemerintah yang berkuasa de facto di Jawa, Madura, dan Sumatra. Ketiga, Pemerintah RI telah mendapat pengakuan de facto dari beberapa negara, seperti Inggris, Amerika Serikat, India, dan Australia. Sementara itu, negara-negara Arab, seperti Mesir, Syria, dan Irak sudah memberi pengakuan diplomatis dan persetujuan persahabatan (Roem 1980: 62).

Berkat usaha negara berdaulat tersebut, masalah RI berhasil diajukan kepada Dewan Keamanan PBB pada Agustus 1947 dan resolusi tentang gencatan senjata yang merupakan suatu kemenangan diplomasi bagi RI. Sejak itu, konflik antara Indonesia dan Belanda tidak lagi semata-mata konflik antarnegara, tetapi suatu masalah internasional yang dibahas di forum dunia. Pada Agustus 1947, PBB mengeluarkan suatu resolusi mengenai pembentukan Komisi Jasa Baik (Good Office Committee) (Bandoro 1991: 52). Dalam hal itu, Belanda menentang pengiriman komisi yang bertugas untuk menyelidiki kekejaman tentara Belanda dan Sekutu di Indonesia. Namun, Belanda tidak dapat membantah pengiriman komisi tersebut karena Inggris dan Ukraina menyetujuinya. Sementara itu pihak Belanda mengharapkan bahwa di dalam perundingan dengan RI, Komisi Jasa Baik tidak menjadi penengah karena perundingan ini adalah urusan rumah tangga Belanda sendiri (Raliby 1960: 237).

Dalam satu wawancara dengan surat kabar Mesir, Al-Misry 6 Agustus 1947, Syahrir mengungkapkan kekejaman tentara Belanda dan Sekutu (ketika itu Syahrir singgah di Kairo dalam perjalanannya menuju New York untuk menghadiri sidang Dewan Keamanan PBB). Pada kesempatan itu, dia menyatakan, bahwa Inggris dan Amerika Serikat (AS) bertanggung jawab atas keadaan RI pada saat itu. Merekalah yang telah menolong negeri Belanda dalam merampas kembali kekuasaan di Indonesia yang telah bebas dari kolonialisme dan imperialisme Belanda setelah kekalahan Jepang. Tentara Belanda memerangi RI dengan senjata Inggris dan AS. Divisi yang dikerahkan untuk melakukan perang yang heroik telah mengalami latihan di Inggris, Kanada, dan AS di bawah pimpinan pakar militer kedua negara itu, tetapi mereka memberikan bantuannya dengan cara rahasia. Syahrir yakin bahwa ada perjanjian antara Belanda dan AS yang telah memaksanya berada pada pihak Belanda. Walaupun modal Inggris penting, perkembangan politik dan ekonomi AS menyebabkan Belanda lebih senang menerima nasihat AS dan menyampingkan tawaran Inggris. Oleh karena itu, posisi Lord Killearn dianggap lebih lemah dari AS untuk mempertahankan imperialisme di Indonesia. Sebenarnya, Pemerintah Inggris telah menyetujui pemakaian Singapura sebagai basis strategis dalam perang untuk menundukkan RI yang telah menuntut kemerdekaan penuh dan evakuasi total bangsa Belanda dari negeri Indonesia (Waal 1947: 285-286).

Masalah Indonesia di dalam sidang Dewan Keamanan PBB menjadi salah satu perdebatan yang rumit dan cukup panjang karena sikap Belanda yang masih menganggap wilayah Indonesia sebagai wilayah kekuasaannya. Perdebatan berakhir setelah disetujui pemungutan suara yang dipimpin oleh 
wakil Syria sebagai ketua sidang Dewan Keamanan PBB pada waktu itu dengan suara 8 setuju lawan 3 tidak setuju. Kelompok yang setuju adalah Australia, Brasil, Cina, Kolumbia, Polandia, Syria, Uni Soviet, dan Amerika Serikat, sedangkan yang menolak adalah Belgia, Prancis, dan Inggris. Keberhasilan diplomasi RI yang didukung oleh wakil negara berdaulat di PBB tidak terlepas dari perjuangan fisik seluruh rakyat Indonesia yang gigih mengusir tentara Belanda dari tanah air mereka.

\section{Misi DiPlomatik Ri Di MesiR}

\section{POlitik LuAR NeGERI MESIR}

Mesir adalah sebuah negara Arab yang menjadi pelopor dan pemimpin organisasi Liga Arab. Negara Republik Arab Mesir (Al-Jumhuriyyatul-Misri Al'Arabiyyah) beribu kota Kairo. Letak geografis wilayah Mesir sangat strategis dan subur dengan sungai Nilnya sehingga sering menjadi incaran negara lain sepanjang sejarah. Pada masa Perang Dunia II, Mesir di bawah Raja Faruk, banyak menghadapi masalah sulit dalam negeri dan luar negeri karena pada waktu itu Mesir di bawah kekuasaan Turki yang kalah perang. Pemberontakan yang dilakukan oleh kalangan sipil dan militer di dalam negeri kerap terjadi. Hal tersebut disebabkan oleh ketidakmampuan pemerintah untuk mengatasi masalah ekonomi yang kian merosot dan korupsi yang merajalela. Sementara itu, gerakan Ikhwanul Muslimin (Persaudaran Muslim) di bawah pemikir Islam cemerlang Hassan Al-Banna berkembang sangat pesat di Kairo pada tahun 1932 dan mendapat sambutan dari masyarakat yang berupaya menghapuskan kebobrokan dalam tubuh pemerintahan. Gerakan itu berusaha meluruskan pelaksanaan Syari'at Islam bagi seluruh bangsa Mesir yang sebagian besar Muslim (Baswedan 1978: 55).

Raja Faruk (1936-1952) sebagai Raja terakhir dalam sistem pemerintahan monarki. Mesir memasuki fase politik internasional dengan bangkitnya kekuatan Uni Soviet dan Amerika Serikat, bersamaan dengan kemunduran pengaruh Barat-khususnya Inggris - di Arab, meluasnya partai politik rakyat, dan tegaknya kelompok politik dan kelompok Islam. Walaupun pengaruh Inggris begitu kuat dan lingkungan pendidikan yang konservatif, Raja Faruk sangat akomodatif dalam memperjuangkan kemerdekaan Mesir dari Inggris karena memperoleh dukungan dari kalangan ulama Al-Azhar. Ia juga menerima pembentukan Dewan Perwakilan yang berfungsi untuk memberikan nasihat dan masukan kepadanya sebagai penguasa Mesir.

Dalam masalah pendidikan, Raja Faruk mendukung dan memiliki kontribusi yang besar bagi perkembangan Universitas Al-Azhar dan menerima sejumlah pelarian politis di Kairo. Di samping itu, Raja mendanai program perencanaan negara Mesir sebagai masyarakat Muslim yang diperhitungkan di dunia Islam sejak jatuhnya sistem kekhalifahan. Namun, dalam perjalanan pemerintahannya, ia mendapat pukulan berat dari dalam negeri dan kekuatan internasional. Di dalam negeri, terjadi penentangan kaum oposisi, dan peningkatan kaum fundamental Ikhwanul Muslimin yang menyebabkan 
pemberontakan umum di seluruh Kairo. Pukulan terakhir datang dari militer yang kalah perang melawan Israel pada tahun 1948. Akhirnya, Raja Faruk jatuh karena militer, bukan karena kekalahan dalam bidang politik yang selalu mengadakan penentangan selama pemerintahannya.

Sementara itu, dalam masalah luar negeri, ada kepentingan Sekutu Barat (Inggris, Prancis, dan AS) terhadap Terusan Suez yang menjadikan wilayah Mesir pangkalan operasi Sekutu dalam Perang Dunia II. Begitu juga, munculnya negara Israel di wilayah Arab Palestina atas prakarsa Inggris dalam Deklarasi Balfour menyeret Mesir dalam Perang Arab-Israel pada 1947. Masalah Sudan menjadi salah satu masalah luar negeri yang sangat sulit karena campur tangan Inggris. Keinginan bangsa Mesir untuk dapat hidup merdeka dan menentukan jalannya sendiri menjadi suatu hal yang harus segera diwujudkan. Akhirnya, seluruh bangsa Mesir, baik sipil maupun militer, mengadakan gerakan pembebasan dari kelemahan pemerintahan Raja Faruk, seperti yang dilakukan oleh para "Perwira Bebas" (Al-Dubbat Al-Ahrar) di bawah pimpinan Gamal Abdul Nasir ketika menjadi pelatih tentara di Akademi Kemiliteran di Kairo yang mendapat dukungan kuat dari gerakan Ikhwanul Muslimin.

Ada dua hal yang membangkitkan gerakan revolusi Mesir. Pertama, pengepungan istana Raja Faruk oleh pasukan Inggris pada tahun 1942. Kedua, kekalahan Mesir dalam Perang Arab-Israel pada 1947. Gerakan revolusi Mesir tidak hanya dilakukan dan ditujukan untuk kemerdekaan bangsa Mesir sendiri yang masih berada dalam pengawasan Sekutu, tetapi juga membantu perjuangan negara-negara yang berpenduduk mayoritas Muslim, baik di Afrika maupun Asia.

Pemerintah Mesir mengakomodasi kepentingan politis negara dengan penduduk mayoritas Muslim yang diwakili oleh mahasiswa yang belajar di berbagai perguruan tinggi di Mesir, terutama di Universitas Al-Azhar, Kairo. Kerajaan akan selalu mendukung perjuangan kemerdekaan negara mereka yang berada di bawah kolonialisme dan imperialisme Barat, apalagi jika rakyatnya beragama Islam. Hal itu ditunjukkannya kepada pemerintah Al-Jazair, Tunisia, dan Maroko, tidak lupa juga memperjuangkan bangsa Palestina. Sementara itu, seorang tokoh pejuang Muslim bagi kemerdekaan Maroko Amir Abdulkarim Al-Khattabi memperoleh suaka politis dari Raja Faruk (Baswedan 1978: 55).

Keinginan Pemerintah Mesir untuk menjadi negara terkemuka di kalangan negara-negara Arab yang mayoritas berpenduduk Muslim adalah sama dengan keinginan Raja Faruk yang ingin menjadi khalifah kaum Muslimin. Kesempatan itu digunakan oleh para pembesar istana untuk merealisasikan dukungan mereka bagi bangsa Indonesia, agar Raja dapat mengakui kemerdekaannya. Akhirnya, mereka berhasil meyakinkan Raja Faruk untuk mengakui kemerdekaan RI dan mengadakan perjanjian persahabatan RIMesir. Keberhasilan tersebut membuka jalan bagi pemerintah Mesir dan RI untuk berkiprah dalam percaturan internasional.

Diplomasi RI di Mesir berhasil menarik simpati negara-negara Arab untuk 
mengakui kedaulatan RI. Akan tetapi, tidak sedikit faktor pendukung dan penghambat usaha tersebut. Faktor pendukung keberhasilan diplomasi RI di antaranya ialah peran Liga Arab di bawah pimpinan Abdurrahman Azzam Pasya yang memiliki tanggung jawab yang besar untuk mempersatukan umat Islam. Selain itu, keberhasilan tersebut didukung oleh surat kabar Arab yang menyuarakan kemerdekaan RI. Adapun faktor penghambat tentang pengakuan kemerdekaan RI adalah ketatnya pengawasan pihak Belanda melalui Kedutaan Besarnya yang mendapat dukungan dari Sekutu yang memiliki kewenangan di negara-negara Arab setelah Perang Dunia II. Kaki tangan Belanda juga berperan untuk menghalangi upaya diplomasi yang dilakukan oleh misi diplomatik RI.

Di antara faktor pendukung keberhasilan diplomasi RI, antara lain adanya peran Liga Arab dan kontribusi surat kabar Arab. Liga Arab didirikan pada bulan Maret 1945 oleh tujuh negara Arab (Mesir, Irak, Saudi Arabia, Yordania, Libanon, Yaman, dan Syria) setelah mengadakan kongres di Iskandariyah, Mesir, pada September 1944. Adapun tujuan Liga Arab adalah memperkuat hubungan antara negara-negara anggota, menyatukan politik luar negeri, dan menjamin kemerdekaan dan kedaulatannya, mengadakan kerja sama di bidang ekonomi, keuangan, kebudayaan, dan lalu lintas. Untuk tujuan ini dibentuk suatu Dewan yang terdiri dari seorang wakil setiap negara anggota, dan berkedudukan di Kairo. Cita-cita persatuan Arab merupakan usaha kolektif negara Arab untuk menghadapi tekanan atau intervensi luar. Pembentukan Liga Arab, selain bertujuan menyatukan negara-negara Arab, merupakan suatu pernyataan sikap tegas Arab dalam menghadapi gerakan zionisme di Palestina.

Hubungan Indonesia-Mesir dan negara-negara Arab bertambah luas dan terarah dengan terbentuknya Liga Arab. Eratnya hubungan tersebut telah dimulai sejak sebelum terbentuk Liga Arab. Untuk mendukung perjuangan bangsa Indonesia yang berjumlah 70 juta jiwa dengan 90 persen lebih beragama Islam, Liga Arab sejak awal berdirinya telah dapat menerima permohonan mahasiswa Indonesia yang mengusulkan agar negara-negara Arab membantu perjuangan RI dalam memperoleh kemerdekaan. Tokoh Liga Arab yang berperan dalam menggalang negara-negara Arab untuk mendukung perjuangan kemerdekaan RI dan memperoleh pengakuan tersebut ialah Sekretaris Jenderal Liga Arab Abdurrahman Azzam Pasya. Dia salah seorang tokoh Liga Arab yang memiliki pengalaman hukum internasional yang luas dan menjadi perhatian para wakil kedutaan asing di Mesir. Duta Besar Belanda di Mesir, dalam laporannya, menyatakan bahwa Mohammad Azzam Pasya beserta rekan-rekan yang berada dalam Liga Arab memiliki pengalaman hukum (Waal 1947: 88 - 89).

Untuk memperoleh informasi yang sebenarnya di Indonesia, Abdurrahman Azzam Pasya mengusulkan kepada Duta Besar Belanda untuk mengirim wakil Liga Arab ke Indonesia agar dapat mengadakan kontak secara resmi dengan Pemerintah RI dan kemungkinan untuk mendirikan Konsulat Mesir di sana. Dia menambahkan bahwa AS dan Inggris telah menyaksikan secara 
langsung kejadian di Indonesia setelah kekalahan Jepang dari Sekutu. Usul tersebut diteruskan oleh Duta Besar Belanda di Mesir kepada Menteri Luar Negeri Belanda di Den Haag dan mengharapkan agar permohonan Abdurrahman Azzam Pasya dapat dikabulkan oleh Pemerintah Belanda. Dengan demikian, Liga Arab dapat melihat sendiri keadaan sebenarnya dan tidak dipengaruhi oleh mahasiswa Indonesia di Mesir yang sudah nyata bersikap sangat nasionalis. Jika permintaan tersebut ditolak, masyarakat Arab akan mendapat kesimpulan yang buruk dan membuka jalan untuk pemerintahan yang meragukan.

Namun, usul itu kurang mendapat perhatian dari Pemerintah Belanda karena Indonesia dianggap belum sepenuhnya merdeka dan baru menuju ke arah sana. Izin masuk wakil Liga Arab ke Indonesia dan pendirian Konsulat negara-negara Arab tidak mendapat tanggapan dari Belanda. Akhirnya, dengan tanggung jawab yang besar terhadap persaudaraan Muslim, Abdurrahman Azzam Pasya sebagai pimpinan Liga Arab dan wakil Pemerintah Mesir mengutus Konsul Jenderal Mesir di India, Mohammad Abdul Mun'im untuk bertemu langsung dengan para pemimpin RI walaupun seluruh wilayah RI diblokade oleh tentara Belanda. Dalam forum PBB, Liga Arab di bawah Abdurrahman Azzam Pasya menunjukkan simpatinya yang besar terhadap usaha diplomasi RI untuk mencari pengakuan internasional. Masalah yang dihadapi Liga Arab sebenarnya begitu berat, seperti masalah Palestina, Terusan Suez, Sudan, dan masalah tentara protektorat Inggris dan Prancis di negara-negara Arab. Namun, perhatian pada masalah Indonesia menjadi prioritas utama. Hal itu ditunjukkan dalam sidang Dewan Keamanan PBB pada Agustus 1946 di New York: masuknya masalah Indonesia dalam agenda sidang. Abdurrahman Azzam Pasya melakukan diplomasi dengan para diplomat asing dan wakil anggota PBB, seperti Amerika Serikat, Australia, India, Afghanistan, dan Filipina untuk membicarakan agresi militer Belanda dan perjuangan kemerdekaan yang dilakukan oleh 70 juta rakyat Indonesia. Pada kesempatan itu, Abdurrahman Azzam Pasya meminta dukungan dari Pemerintah India melalui kawat yang disampaikannya kepada Perdana Menteri Jawharlal Nehru untuk mendukung Indonesia dan mengadukannya kepada sidang Dewan Keamanan PBB. Selain itu, ketika delegasi RI di bawah pimpinan Sutan Syahrir menghadapi kendala keuangan selama mereka berada di New York, Abdurrahman Azzam Pasya memberikan pinjaman sebesar 20 ribu dolar Amerika yang diperoleh dari Mahmud Abu Al-Fath, seorang editor surat kabar Mesir, Al-Misry. Lima bulan kemudian, Pemerintah RI mengembalikan uang pinjaman tersebut (Roem 1986: 72-73).

Keberhasilan memasukkan masalah Indonesia dalam sidang Dewan Keamanan PBB memperkuat kembali keputusan Liga Arab dalam menyatukan politik luar negeri mereka untuk mendukung kedaulatan dan kemerdekaan negara-negara Muslim yang terjajah. Dukungan diplomasi Liga Arab dalam forum internasional merupakan pembuka jalan bagi RI yang baru lahir untuk dapat hidup berdampingan dengan negara berdaulat lainnya. 
Faktor positif lain yang mendukung keberhasilan diplomasi RI adalah dukungan dari para pemimpin surat kabar Mesir yang meliputi perjuangan kemerdekaan. Opini surat kabar Mesir tentang RI tersebut mencerminkan kenyataan yang hidup dalam masyarakat Arab yang mendukung bangsa Indonesia. Hal itu menunjukkan solidaritas bangsa Mesir terhadap RI setelah surat kabar menyebarluaskannya ke semua negara Arab. Di antara surat kabar yang aktif dalam mempromosikan perjuangan mahasiswa Indonesia adalah Al-Ahram, Ikhwanul Muslimin, Al-Mukattam, Al-Dustur, Al-Kutlah, dan Al-Misry.

Sebuah laporan surat kabar Mesir yang menjadi sorotan Duta Besar Belanda tentang berita pengakuan Pemerintah Mesir terhadap kemerdekaan RI adalah Al-Ahram. Dalam laporan No. 136, Tanggal 14 Juni 1947, Duta Besar Belanda melaporkan berita Kementerian Luar Negeri Kerajaan Mesir menjawab surat No. 299/PI tanggal 4/6/47 dari Kedutaan Belanda yang diterbitkan Al-Ahram tanggal 3/6/47. Berita pengakuan Pemerintah Mesir itu memang benar dan tepat karena para Menteri telah menetapkan untuk mengakui RI pada tanggal 1 Juni 1947 (Waal 1947: 299 - 300).

Masyarakat Arab dapat mengakses langsung informasi pergerakan dan perjuangan dari Indonesia berkat kantor berita The Arabian Press Board (APB). APB berperan mendukung perjuangan dan menjadi saksi langsung pergerakan kemerdekaan RI. Berita tentang Indonesia disiarkan ke semua negara Arab melalui Radio Republik Indonesia (RRI) di Yogyakarta. Salah satu isi berita APB adalah situasi keamanan dan kehidupan sehari-hari masyarakat Indonesia di Yogyakarta setelah proklamasi kemerdekaan. Situasi ibu kota negara penuh dengan ketenteraman dan kedamaian penduduknya dalam menunaikan tugas sehari-hari. Mereka selalu membuka telinga untuk memperoleh informasi dari dunia luar untuk memperoleh kemajuan.

Dalam upaya menghambat kedatangan "misi Belanda" ke negaranegara Arab untuk menggagalkan perjuangan kemerdekaan dan diplomasi RI di negara-negara Arab, APB menggalang semua surat kabar Arab untuk menyiarkan berita dengan judul "Rombongan Pengkhianat akan Mengunjungi Negara-Negara Arab", "Propagandis Belanda", dan "Pedagang Belanda". Berita dengan judul "Propagandis Belanda" yang mengisi semua surat kabar Arab menyatakan bahwa akan sampai ke negaranegara Arab serombongan propagandis Belanda dipimpin oleh Muhammad bin Abdullah Alamudi, orang yang terkenal memusuhi Pemerintah RI dan kesetiaannya kepada Pemerintah Belanda. Selain itu, rombongan tersebut terkenal dengan tindakannya menentang pendirian komite penyokong Palestina. Dia bermaksud akan mempropagandakan Belanda dan membuat berita buruk tentang RI. Dalam hal itu, masalah Palestina dijadikan jembatan untuk mengadakan hubungan dengan para pemimpin Arab di negaranegara Arab. Upaya para pemimpin surat kabar Arab dalam mendukung perjuangan RI menghambat usaha Belanda untuk menggagalkan diplomasi yang dijalankan Misi Diplomatik RI. 


\section{Perjanitan Persahabatan RI-Mesir}

Usul Konsul Jenderal Mesir Mohammad Abdul Mun'im yang disampaikan dalam konferensi pers di Yogyakarta, ketika diterima oleh Presiden Soekarno dan bertukar pikiran dengan para pembesar RI di Yogyakarta, berhasil meyakinkan pemerintah RI untuk mengirimkan sebuah misi diplomatik RI ke negara-negara Arab. Misi yang dipimpin oleh H. Agus Salim berangkat dari Yogyakarta dengan pesawat yang dinaiki Mohammad Abdul Mun'im menuju Singapura dan dia melanjutkan perjalananannya ke Mesir untuk melaporkan perjalanannya kepada Raja Faruk dan kepada Sekjen Liga Arab, sedangkan rombongan delegasi RI meneruskan perjalanan mereka ke New Delhi, India, untuk menghadiri Inter Asian Relation Conference.

Pada tanggal 10 April 1947, rombongan delegasi Indonesia untuk negaranegara Arab sampai di Kairo dengan perlengkapan yang sangat sederhana dan berbekal dokumen perjalanan semacam paspor yang dikeluarkan oleh Kementrian Luar Negeri RI. Di depan anggota Panitia Pusat, H. Agus Salim, Ketua Delegasi menyampaikan ucapan terima kasihnya kepada Panitia. Setelah mengadakan pertemuan dengan Panitia Pusat, delegasi ini mengadakan kunjungan kehormatan kepada Raja Faruk di Isatana Abidin, sedangkan Abdurrahman Azzam Pasya, Sekjen Liga Arab dalam hal ini bertindak sebagai tuan rumah.

Kunjungan kehormatan kedua dilakukan kepada Mahmud Nokrasyi Pasya, Perdana Menteri Mesir merangkap Menteri Luar Negeri, di Kementerian Luar Negeri Mesir. Dalam pertemuan tersebut dinyatakan, bahwa kunjungan delegasi RI ke negara-negara Arab adalah untuk mengadakan hubungan diplomatik. Karena kondisi politis Mesir pada saat itu kurang menguntungkan, delegasi RI terpaksa menunggu sampai tiga bulan sebelum semua pekerjaan selesai.

Perjanjian Persahabatan, Politik, dan Perdagangan Indonesia-Mesir baru ditanda-tangani oleh kedua negara di Kementerian Luar Negeri Mesir di Kairo pada tanggal 10 Juni 1947. Pihak Mesir diwakili oleh Perdana Menteri merangkap Menteri Luar Negeri, Nokrasyi Pasya, sedangkan pihak RI diwakili oleh Menteri Muda Luar Negeri, H. Agus Salim. Adapun naskah Perjanjian Persahabatan Indonesia Mesir ini ditulis dalam Bahasa Arab dan Prancis.

Setelah Perjanjian Persahabatan ditandatangani, H. Agus Salim memutuskan untuk segera menyampaikan naskah perjanjian dan laporan perjalanan mereka selama di negara-negara Arab kepada Presiden Soekarno di Yogyakarta. Hal ini dilakukan karena situasi gawat di Indonesia setelah seruan Panglima Besar Soedirman kepada rakyat Indonesia untuk bersiap siaga terhadap ultimatum Belanda. Selain itu, Perjanjian Persahabatan yang ditandatangani oleh Pemerintah RI dan Pemerintah Mesir menyebabkan semangat bertahan dari pihak RI terhadap ultimatum Belanda tidak turun. Untuk menyampaikan naskah perjanjian tersebut ke Indonesia, H. Agus Salim mengutus A.R. Baswedan agar segera kembali ke tanah air. 
Pada tanggal 18 Juni 1947, A.R. Baswedan bertolak dari Kairo dengan pesawat BOAC ke Singapura. Selama perjalanan, tidak sedikit kesulitan yang dialaminya. Akhirnya, pada 13 Juli 1947, dengan susah payah dia tiba dengan pesawat KLM di Indonesia. Pada 19 Juli 1947, dia bertolak dari Jakarta bersama dengan Mr. Amir Syarifuddin ke Yogyakarta untuk melaporkan kepada Presiden Soekarno perihal kunjungan mereka di negara-negara Arab dan hasil yang mereka peroleh.

Perjanjian Persahabatan ini mematahkan kepungan Diplomasi Belanda terhadap RI walaupun Duta Besar Belanda di Mesir berusaha untuk memprotes kepada Perdana Menteri Mesir. Akan tetapi, dengan jiwa Islam yang tinggi Nokrasyi menjawab: "Menyesal sekali kami harus menolak protes tuan, sebab Mesir selaku negara berdaulat, dan sebagai negara yang berdasarkan Islam, tidak dapat tidak mendukung perjuangan bangsa Indonesia yang beragama Islam. Ini adalah tradisi bangsa Mesir dan tidak dapat diabaikan." Setelah perjanjian dengan Mesir selesai, misi Diplomatik RI berkeliling ke negaranegara Arab untuk mencari pengakuan Kemerdekaan RI.

Keberhasilan diplomasi RI tidak terlepas dari hambatan yang dialami delegasi Indonesia. Hambatan yang dijumpai antara lain adanya pengawasan dan campur tangan Kedutaan Belanda serta kaki tangan mereka. Pihak Kedutaan berusaha memengaruhi mahasiswa Indonesia untuk mengakui kedaulatan Belanda di Indonesia dengan imbalan uang tunjangan dari Pemerintah Belanda. Sampai akhir November 1945 pembayaran uang tunjangan dari Pemerintah Belanda telah diterima oleh mahasiswa tanpa masalah. Syekh Ruak Indonesia (pemimpin para mahasiswa di Asrama al-Azhar) biasanya mengambil jumlah uang yang akan dibagikan pada mahasiswa Indonesia dan dia mengatakan bahwa tidak seorang Indonesia pun yang tidak menghargai uang tunjangan itu. Akan tetapi, mulai 1 Maret 1946 para mahasiswa tidak mau lagi menerima bantuan karena harus menandatangani kuitansi yang dikeluarkan oleh Pemerintah Belanda, sedangkan mahasiswa hanya mau mengakui Pemerintah RI.

Keputusan untuk menolak bantuan dari Pemerintah Belanda telah diserahkan oleh Syekh Abdul Salam yang telah ditandatangani oleh 83 orang mahasiswa. Para mahasiswa sebaliknya mau menandatangani bantuan itu jika sebagai "utang" bukan sebagai "pemberian" yang dikaitkan dengan kekuasaan Belanda di Indonesia. Dasar pertimbangan mereka adalah bahwa "pemberian" akan memberikan "kedudukan" bagi Pemerintah Belanda, sedangkan "utang" memberikan "kebebasan" untuk bertindak. Dalam hal itu, Duta Besar Belanda menyatakan dengan sinis, bahwa kebanggaan nasional seperti yang disebarluaskan dalam laporan surat-surat kabar Arab tidak bertahan terhadap kebutuhan dunia. Adapun alasan penerimaan bantuan tersebut adalah agar perjuangan mahasiswa tetap dapat dilakukan walaupun bantuan yang diberikan dari keluarga mereka di Indonesia terputus karena adanya blokade Belanda. Sampai bulan Maret 1946, bantuan yang diberikan oleh Pemerintah Mesir setelah terputusnya bantuan Belanda tidak mencukupi untuk menutupi kebutuhan hidup setiap hari. Untuk menarik 
perhatian umum, warga Indonesia menduduki Kedutaan Besar Belanda agar Pemerintah Belanda memberikan bantuan keuangan. Tuntutan mahasiswa berhasil diterima oleh Pemerintah Belanda setelah pihak kepolisian Mesir turun tangan. Pemerintah Belanda terpaksa memberikan bantuan keuangan yang sangat minim kepada mahasiswa Indonesia di Mesir.

Seharusnya Belanda memberikan bantuan seperti yang dilakukan oleh Pemerintah Prancis terhadap orang-orang muslim Afrika Utara, tidak peduli apakah mereka anti atau setuju dengan Prancis. Begitu juga sikap yang ditunjukkan oleh Pemerintah Inggris walaupun posisi kekuasaannya di Mesir mengungkapkan anti Inggris yang begitu hebat ditulis di dalam surat-surat kabar Mesir, posisi kekuasaan itu tetap saja ditelan oleh orang Inggris. Hal tersebut dikemukakan oleh Sekretaris Urusan Timur dari Kedutaan Prancis, Soulie kepada Duta Besar Belanda di Mesir dalam menanggapi sikap Pemerintah Belanda yang tidak mau membantu mahasiswa Indonesia dalam perjuangan kemerdekaan.

Sementara itu, setiap kegiatan yang berhubungan dengan perjuangan mahasiswa Indonesia di Mesir menjadi laporan utama Duta Besar Belanda. Salah satu kegiatan yang dilakukan oleh 2 orang anggota pengurus Perhimpunan Kemerdekaan Indonesia di Port Said dilaporkan oleh Duta Besar Belanda pada tanggal 12 Nopember 1945. Pada waktu itu, beberapa anggota Perhimpunan pergi ke Suez dan Port Said melakukan agitasi di antara pelautpelaut Indonesia dan berhasil mengumpulkan sejumlah uang di salah satu kapal yang mereka datangi. Selain itu, Duta Besar Belanda melaporkan tentang kegiatan 2 orang wakil Indonesia-Kairo (Fuad Syadzili dan Said Mahjuddin dari Padang) yang telah berusaha pergi ke Mekkah untuk melakukan propaganda RI di antara jama'ah haji Indonesia. Dengan bersembunyi di bawah "pergi haji", upaya propaganda tersebut mudah dilakukan.

Sentimen agama dan sentimen anti Sekutu yang dipropagandakan oleh mahasiswa Indonesia berhasil menghilangkan keraguan terhadap perjuangan kemerdekaan RI, bahkan menambah kuat simpati dan dukungan negaranegara Arab. Salah satu masalah yang dilaporkan kaki tangan Belanda di Mesir, Syekh Yusuf Jawawi adalah kedatangan "misi haji" Panitia Negara Arab ke Mekkah pada bulan Nopember 1945. Misi haji dan sekaligus konferensi Paniti Pusat itu diwakili oleh Fuad Mohammad Fakhruddin dan Said Mahjuddin (Kairo), Syafi'i Abdul Karim (Baghdad), dan Ja'far Jaenuddin, Nur Encik dan Abdul Latif Sijanten (Saudi Arabia).

Dalam pertemuan di kota Mekkah itu, anggota Panitia Pusat mengharapkan kepada setiap haji dari seluruh dunia agar menjadi penghubung di negeri mereka masing-masing dalam mendukung perjuangan kemerdekaan RI dan mendorong pemerintah mereka untuk mengakui RI. Misi tersebut membagikan brosur-brosur di kalangan jamaah haji yang berisi penerangan tentang situasi sebenarnya yang terjadi di Indonesia, bantahan bahwa RI adalah Made in Japan, dan Soekarno-Hatta adalah "boneka-boneka yang digerakkan militer Jepang". Untuk itu, kaum muslimin harus bersatu dalam mempertahankan hak-hak kemerdekaan mereka dari penindasan kaum penjajah yang bersatu 
untuk menghancurkan umat Islam. Ketika pengakuan kemerdekaan de facto diberikan oleh Pemerintah Mesir, pihak Kedutaan Besar Belanda berusaha keras untuk menggagalkan pengakuan tersebut dengan menempatkan orangorang Indonesia yang bekerja sebagai kaki tangannya dengan mengintrodusir sentimen anti Islam dan anti Arab. Untuk menyebarluaskan berita tersebut, Belanda menempatkan Salim Al-Atas sebagai atase pada Kedutaan Besar Belanda di Kairo. Akan tetapi, atas usaha Panitia Kairo, Salim Al-Atas dapat diusir dari Mesir sebagai persona non-grata. Selain itu, kaki tangan Belanda yang dikirim dalam sebuah "misi diplomatik Belanda" ke negara-negara Arab di bawah pimpinan Sultan Pontianak, Abdul Hamid juga dapat digagalkan. "Misi Haji" Belanda ke Mekkah juga dikirim ke Mesir untuk menghalangi pengakuan tersebut, tetapi mereka dapat diusir dari Mesir.

Sebuah misi mata-mata Belanda dari Indonesia yang menjadi berita besar di kalangan surat kabar Arab adalah misi yang dipimpin Muhammad bin Abdullah Alamudi dengan anggotanya Ali Bin Sungkar, Abdul Kadir Audah, Ahmad Martak, dan Zein Bajeber untuk menggagalkan usaha diplomasi RI di Timur Tengah. Mereka dikirim secara rahasia untuk mengunjungi negara-negara Arab demi kepentingan Belanda dan menentang RI. Dalam hal itu, masalah Palestina mereka jadikan jembatan untuk dapat mengadakan pendekatan dengan para pembesar Arab. Atas usaha keras The Arabian Press Board (A.P.B.) rencana kedatangan mata-mata Belanda itu telah tersebar di seluruh surat kabar Arab. Selain itu, pihak keamanan negara Arab yang akan dikunjungi telah mengantisipasi kedatangan mereka. Ketika tiba di Kairo, mereka tercengang dan terperanjat atas sikap masyarakat di sana yang sangat berlainan, karena terdapat tuduhan bahwa mereka adalah mata-mata Belanda. Dalam kesempatan itu, empat orang dari mata-mata Belanda, selain Alamudi, mencari perlindungan sambil menyatakan bahwa mereka bersih dari segala tuduhan yang telah disiarkan surat kabar Mesir. Mereka mengakui bahwa Alamudi memang seorang propagandis Belanda. Di Saudi Arabia, "misi haji dan cita-cita Palestina Alamudi dan kawan-kawan" dapat digagalkan dan diusir atas perintah Raja.

\section{Pengakuan de Jure RI dari Negara-negara Arab}

Perjanjian Persahabatan Indonesia-Mesir tanggal 10 Juni 1947 seakan memicu negara-negara Arab yang telah merdeka untuk berusaha mengakui kemerdekaan RI dan melakukan perjanjian persahabatan di antara mereka. Kontribusi Liga Arab begitu besar dalam menghubungi negara-negara anggotanya untuk menerima misi diplomatik RI sebagai tamu negara. Hal ini ditunjukkan oleh Abdurrahman Azzam Pasya yang memberi dukungan selama kunjungan misi diplomatik ini ke seluruh negara Arab. Negara-negara Arab yang dikunjungi adalah Syria, Yordania, Irak, Libanon, Saudi Arabia, dan Yaman.

Negara Arab pertama yang dikunjungi misi diplomatik RI, setelah penandatanganan Perjanjian Persahabatan Indonesia-Mesir, adalah Syria. Di Damaskus, delegasi RI mendapat sambutan resmi pemerintah dan rakyat 
Syria. Pada tanggal 2 Juli 1947 telah ditandatangani Perjanjian Persahabatan, Hubungan Diplomatik dan Konsuler antara Pemerintah RI dan Republik Syria. Pihak Indonesia diwakili oleh H. Agus Salim, sedangkan pihak Syria diwakili oleh Jamil Mardam Bey, Menteri Luar Negeri Syria. Naskah Perjanjian tersebut sama isinya dengan Perjanjian Persahabatan Indonesia-Mesir, tetapi tidak memasukkan Perjanjian Perdagangan. Dalam perjalanan selanjutnya, perjanjian persahabatan antara RI dan Syria diratifikasi oleh Komite Kerja Pusat Parlemen Sementara RI yang disiarkan dalam "Lembaran Negara" pada tahun 1948.

Setelah Pengakuan dan Perjanjian Persahabatan dari Syria diperoleh, misi diplomatik RI melanjutkan perjalanan ke Amman, ibu kota Yordania yang berpenduduk 300.000 jiwa dan seluruh anggaran belanjanya masih dibantu Inggris (1947). Pada waktu itu, Amir Abdullah meminta kepada misi diplomatik RI ini agar formalitas pengakuan kemerdekaan ditangguhkan. Walaupun demikian, dalam kenyataannya pemerintah Yordania mendukung keputusan Liga Arab pada 18 November 1946 untuk mengakui kemerdekaan RI.

Misi diplomatik RI selanjutnya meneruskan kunjungan ke Baghdad, Irak. Sambutan rakyat dan pemimpin Irak sangat meriah walaupun dalam hal pengakuan kemerdekaan RI masih dipertimbangkan karena kuatnya pengaruh Inggris yang mendukung Belanda di wilayahnya. Pada kenyataannya, Irak telah mengumumkan pengakuannya atas kemerdekaan RI seperti yang dinyatakan Liga Arab, tetapi masih menangguhkan penandatanganan perjanjian persahabatan seperti yang dilakukan oleh Pemerintah Mesir. Setelah melakukan kunjungan resmi di Irak, misi diplomatik RI ini melanjutkan kunjungan mereka ke Libanon, bertepatan dengan serangan militer pertama Belanda terhadap wilayah RI. H. Agus Salim sebagai ketua delegasi ini meragukan sikap Pemerintah Libanon yang tidak akan mengakui kemerdekaan RI karena Pemerintah Libanon dekat dengan bangsa Barat. Akan tetapi, Riadh Solh Bey, Perdana Menteri Libanon, pernah menyaksikan "Film Proklamasi" ketika hadir dalam resepsi misi diplomatik RI di Kairo. Akhirnya, RI mendapat pengakuan Libanon pada 29 Juni 1947 sebagai negara yang merdeka dan berdaulat penuh.

Setelah pengakuan kemerdekaan dari Pemerintah Libanon diperoleh, mulai 7 Agustus 1947 H.M. Rasyidi menjadi ketua misi diplomatik RI untuk negara-negara Arab. Ia menggantikan dan meneruskan usaha H. Agus Salim yang menyertai Perdana Menteri Syahrir untuk menghadiri sidang Dewan Keamanan PBB pada 7 Agustus 1947 (Rasyidi 1978: 23). H.M. Rasyidi berkunjung ke Saudi Arabia pada musim haji tahun 1947 didampingi oleh Sekretaris Jenderal Liga Arab, Abdurrahman Azzam Pasya menghadap Raja Abdul Aziz. H. Agus Salim menyampaikan permohonan maafnya kepada Raja Abdul Aziz Al-Saud melalui H.M. Rasyidi karena tidak dapat melanjutkan perjalanannya ke Jeddah, Saudi Arabia karena pada waktu itu Belanda sedang mengadakan agresi militernya terhadap RI dan H. Agus Salim juga harus mendampingi Perdana Menteri Syahrir menghadiri Sidang Dewan Keamanan 
PBB di New York.

Dalam kunjungan tersebut, Raja Abdul Aziz Al-Saud memberikan Surat Pengakuan Kerajaan Saudi Arabia kepada pemerintah RI pada 21 November 1947. Pada waktu yang bersamaan, pihak Kedutaan Belanda di Saudi Arabia mengutus Sultan Pontianak, Abdul Hamid menghadap Raja Abdul Aziz AlSaud untuk menggagalkan usaha misi diplomatik RI di Saudi Arabia. Usaha kaki tangan Belanda ini tidak berhasil menggagalkan pengakuan Raja Abdul Aziz terhadap kemerdekaan RI di Saudi Arabia.

Kerajaan Yaman, sebagai negara Arab merdeka terakhir yang memberikan pengakuan kemerdekaan RI, pada 20 November 1947 mengakui kemerdekaan RI. Pada waktu itu, Yaman masih tertutup dan belum mempunyai perwakilan di luar negeri selain di Liga Arab. Wakil Kerajaan Yaman di Liga Arab Ali AlMuayyad telah menandatangani Kuasa Usaha RI di Mesir, H.M. Rasyidi untuk menyampaikan pengakuan kemerdekaan RI sebagai negara yang merdeka dan berdaulat. Pengakuan negara-negara Arab ini merupakan keberhasilan Mission Diplomatique RI yang mendapatkan dukungan dari bangsa Arab dan mahasiswa Indonesia yang belajar di Mesir. Simpati negara-negara Arab terhadap perjuangan kemerdekaan RI menyebabkan Pemerintah Belanda mendesakkan keinginannya pada RI untuk menghentikan permusuhan terhadap Belanda. Keinginan Pemerintah Belanda itu ditolak oleh Pemerintah RI. Akibatnya, pada tanggal 21 Juli 1947, Belanda mengadakan agresi militer yang disebutnya sebagai "aksi polisionil" di Indonesia untuk memberi kesan bahwa yang terjadi adalah urusan dalam negeri pemerintah Belanda sendiri dan tidak boleh dicampuri oleh dunia luar.

Dalam Sidang Dewan Keamanan PBB, “aksi polisionil” Belanda yang hendak menghancurkan Negara dan Pemerintah RI mendapat tanggapan dan protes keras dari wakil negara-negara Arab, terutama Mesir dan Syria. Faris Al-Khuri, wakil Syria di PBB sebagai pemimpin sidang pada bulan Agustus 1947 membentangkan pendapat negaranya yang telah membendung usaha kolonial guna menghalangi wakil-wakil RI untuk membicarakan soal negaranya. Pada akhirnya, Faris Al-Khuri berhasil menggagalkan usaha Sekutu untuk memprotes masalah Indonesia masuk dalam agenda sidang Dewan Keamanan PBB. Begitu juga usaha Hafiz Afifi Pasya, wakil Mesir di PBB berhasil meyakinkan dunia internasional akan pentingnya masalah Indonesia menjadi salah satu agenda dalam persidangan tersebut. Untuk meyakinkan para mahasiswa Indonesia di Mesir, Hafiz Afifi Pasya menjawab surat yang diajukan oleh Panitia Pusat di Kairo, seperti berikut.

Yakinlah tuan-tuan bahwa saya akan menyediakan seluruh kemampuan saya guna kepentingan soal Indonesia dan akan mempertahankannya sejauh kemampuan saya itu. Karena Indonesia dan Mesir mempunyai agama, tradisi dan cita-cita yang sama. Saya berkepercayaan seperti tuan-tuan bahwa soal Timur adalah satu dan jauh jarak tidaklah akan melengahkan kami dari pada mempertahankan persoalannya. (Hassan, 1980:112).

Keberhasilan misi diplomatik RI di dalam sidang Dewan Keamanan PBB yang mendapat dukungan bangsa Arab, khususnya Mesir, menjadi perhatian 
dan mendapat penghargaan dari Wakil Presiden RI. Ketika singgah di Mesir dalam perjalanan pulang dari sidang Konferensi Meja Bundar di Den Haag, Drs. Mohammad Hatta mengatakan kepada majalah Akhir Sa'ah, di Kairo, bahwa "kemenangan diplomasi RI sesungguhnya berpangkal di Mesir. Karena dengan pengakuan Mesir dan negara-negara Arab lainnya atas RI sebagai negara yang merdeka dan berdaulat penuh, segala jalan telah tertutup bagi Belanda untuk surut kembali atau memungkiri janji, seperti dilakukannya dahulu"(Hassan 1978: 33-34).

\section{KESIMPULAN}

Diplomasi RI di Mesir berhasil menarik simpati negara-negara Arab untuk mengakui kedaulatan RI, seperti Mesir, Syria, Yordania, Libanon, Irak, Yaman, dan Saudi Arabia. Akan tetapi, tidak sedikit faktor pendukung dan penghambat usaha tersebut. Faktor pendukung keberhasilan diplomasi RI di antaranya ialah peran Liga dan surat kabar Arab yang spontan menyuarakan kemerdekaan RI. Adapun faktor penghambat pengakuan kemerdekaan RI adalah ketatnya pengawasan pihak Belanda melalui Kedutaan Besarnya yang mendapat dukungan dari Sekutu yang memiliki kewenangan di negaranegara Arab setelah Perang Dunia II.

Latar belakang dukungan Mesir terhadap perjuangan kemerdekaan RI dan pencarian pengakuan dunia internasional adalah keinginan Mesir untuk mengisi kekosongan kekhalifahan umat Islam setelah tumbangnya kekuasaan Turki yang pernah menjadi pemersatu umat Islam di negara-negara Arab. Selain itu, Mesir melalui Liga Arab ingin membantu semua negara yang mayoritas penduduknya Muslim agar dapat lepas dan merdeka dari kolonialisme dan imperialisme.

\section{DAFTAR ACUAN}

Abaza, Mona. 1999. Pendidikan Islam dan Pergeseran Orientasi. Jakarta: LP3ES

Abdulgani, Roeslan. 1978. "Hubungan Indonesia dengan Mesir dan Timur Tengah Sepanjang Sejarah." dalam Sekitar Perjanjian Persahabatan Indonesia-Mesir. Jakarta: Panitia Peringatan HUT Ke-32 Perjanjian Persahabatan Indonesia Mesir.

Agung, Ide Anak Agung Gde. 1973. Twenty Years Indonesian Foreign Policy 1945-1965. Paris: Mouton \& Co.

Alatas, Ali. 1995. “Sambutan Menteri Luar Negeri RI” dalam Seminar Hubungan Indonesia Mesir Dilihat dari Tinjauan Sejarah. Jakarta: Departemen Luar Negeri RI.

Baswedan, A. R. “Catatan dan Kenangan” dalam Sekitar Perjanjian Persahabatan Indonesia-Mesir Tahun 1947. Jakarta: Panitia Peringatan HUT Ke-32 Perjanjian Persahabatan Indonesia - Mesir.

Bandoro, Bantarto. 1991. “Diplomasi Indonesia: Dahulu, Kini, dan Masa Depan” dalam Hadi Susastro (ed.). Untuk Kelangsungan Hidup Bangsa. Jakarta: CSIS.

Hassan, M. Zein. 1980. Diplomasi Revolusi Indonesia di Luar Negeri. Jakarta: Bulan Bintang.

Leifer, Michael. 1989. Politik Luar Negeri Indonesia. Jakarta: Gramedia.

Leirissa, R.Z. 1997. "Historiografi: Suatu Tinjauan Kritis” dalam Pidato Pengukuhan Guru Besar Madya Tetap Fakultas Sastra Universitas Indonesia. Depok: FSUI.

Raliby, Osman. 1960. Historia Documenta. Djakarta: Bulan Bintang.

Rasyidi, H.M. 1978. “Negara-Negara Arab Adalah yang Pertama Mengakui Kemerdekaan Bangsa Indonesia" dalam Sekitar Perjanjian Persahabatan Indonesia Mesir Tahun 1947. Jakarta: Panitia Peringatan HUT Ke-32 Perjanjian Persahabatan Indonesia - Mesir. 
Roy, S.L. 1990. Diplomasi. Terj. Herwanto dan Mirsawati. Jakarta: Rajawali Pers.

Roem, Mohammad. 1986. Diplomasi: Ujung Tombak Perjuangan RI. Jakarta: Gramedia.

Soesastro, Hadi (ed.). 1991. Untuk Kelangsungan Hidup Bangsa. Jakarta: CSIS.

Suwarno, Basuki. 1988. Hubungan Indonesia-Belanda Periode 1945 - 1950. Jakarta: Upakara.

Tantri, K'tut. 1965. Revolusi di Nusa Damai. Terj. Maj. Abd. Salim. Djakarta: Gunung Agung.

Waal, S.L. van der. 1988. Officiele Bescheiden Betreffende de Nederlands-Indonesische Betrekkingen 1945-1950. 's- Gravenhage: Martinus Nijhoff (21 jilid). 